\title{
Gamma-interferon activates a nuclear protein that binds to the gamma-interferon activation site of the thyroglobulin gene
}

\section{A W C Kung and K S Lau}

\author{
Department of Medicine, The University of Hong Kong, Queen Mary Hospital, Hong Kong \\ (Requests for offprints should be addressed to A Kung, Department of Medicine, The University of \\ Hong Kong, Queen Mary Hospital, 102 Pokfulam Road, Hong Kong)
}

\begin{abstract}
The release of interferon-gamma (IFN $\gamma)$ has been demonstrated from the infiltrating $\mathrm{T}$ lymphocytes of the thyroid gland from patients with autoimmune thyroid disease (AITD). We have shown previously that IFN $\gamma$ inhibited thyroglobulin (Tg) gene transcription, and that its action was mediated by an increase in intracellular calcium and inositol phosphates. In the present study, we tried to determine the specific site of action of IFN $\gamma$ on the $\mathrm{Tg}$ gene. A $565 \mathrm{bp}$ fragment (position -530 to +34 ) spanning the transcriptional start site of the human Tg promoter was ligated to the luciferase plasmid and transiently transfected into human thyrocytes. Stimulation with TSH $(10 \mathrm{mIU} / \mathrm{l})$ and IFN $\gamma$ (500 IU/1) resulted in a twofold increase and a $60 \%$ reduction in the luciferase activity respectively, similar to the effect observed with the endogenous $\mathrm{Tg}$ gene. Deletion studies revealed that the region with the strongest suppression by IFN $\gamma$ lay between $5^{\prime}-388$ to -258 . Mobility gel shift experiments and DNA footprinting experiments demonstrated
\end{abstract}

that the action of IFN $\gamma$ was mediated through a trans-acting protein which complexed to position -282 to -262 TTGAGCCTGTTCCCTC CAAA. Position -272 to -261 TTCCCTCCAA corresponded to the gamma-interferon activation site (GAS) consensus sequence $\mathrm{TTNC}^{\mathrm{C}}{ }_{\mathrm{T}}$ NNNAA. The turnover time of the nuclear protein lasted for only $4 \mathrm{~h}$ although the suppressive effect of IFN $\gamma$ on $\mathrm{Tg}$ gene transcription lasted for $48 \mathrm{~h}$. The effect of IFN $\gamma$ was lost when the thyrocytes were co-treated with genistein, a specific tyrosine kinase inhibitor.

The presence of the GAS in the promoter sequence of the $\mathrm{Tg}$ gene confirms the specific action of IFN $\gamma$ in thyroid hormone metabolism. In conclusion, apart from its regulatory role in $\mathrm{T}$ cell development and perpetuation of the immune response in AITD, IFN $\gamma$ may also play a role in altering cellular function of the thyrocytes by its action on the $\mathrm{Tg}$ gene promoter.

Fournal of Molecular Endocrinology (1998) 20, 293-298

\section{INTRODUCTION}

Autoimmune thyroid disease (AITD) is a common condition affecting between $2 \%$ and $4 \%$ of the population. The condition is characterized by lymphocytic infiltration of the thyroid gland together with the production of auto-antibodies against thyroid specific antigens, including thyroglobulin, thyroid peroxidase (TPO) and the thyrotropin (TSH) receptor. The intrathyroidal $\mathrm{T}$ lymphocytes are very important in the pathogenesis of AITD through thyroid antigen recognition as an essential step to B cell stimulation and for mediating the release of cytokines (Volpe 1993, Weetman \& McGregor 1994). The clinical presentation of AITD depends on the spectrum of the cytokines and antibodies produced by the activated lymphoid cells, as these cytokines and auto-antibodies are capable of alterating the function and metabolism of the thyroid gland. Among the various cytokines, the action of gamma-interferon (IFN $\gamma$ ) has been the best studied. Functional IFN $\gamma$ receptors have been identified on the thyrocytes, and thus IFN $\gamma$ secreted from the infiltrating lymphocytes can exert a direct effect on the thyroid epithelial cells (Nishikawa et al. 1993). The macrophages and lymphocytes infiltrating the thyroid gland from patients with AITD have been shown to release IFN $\gamma$ into the adjacent thyrocytes (Watson et al. 1994). Enhanced production of IFN $\gamma$ by thyroid-derived $\mathrm{T}$ cell clones from patients with Hashimoto's thyroiditis has been demonstrated (Del-Prete et al. 1987). 
Indeed, in thyroid sections from patients with either Hashimoto's thyroiditis or Graves' disease, class II MHC-positive thyrocytes were found immediately adjacent to aggregates of IFN $\gamma$-positive lymphocytes (Hamilton et al. 1991), suggesting that class II expression by the thyrocytes was secondary to the release of IFN $\gamma$ by the infiltrating $\mathrm{T}$ cells. Furthermore, IFN $\gamma$ inhibited proliferation of thyrocytes and altered the expression of the various thyroid specific proteins (Nagayama et al. 1987, Ashizama et al. 1989, Kung \& Lau 1990, Kung et al. 1992, Watson et al. 1994). All these findings suggest that, apart from its role in the perpetuation of an autoimmune response in AITD, IFN $\gamma$ may also have a direct effect on the cellular function of and the hormone production by the thyrocytes.

We have previously demonstrated that IFN $\gamma$ inhibited thyroglobulin ( $\mathrm{Tg}$ ) gene transcription in human thyrocytes, and that the intracellular signaling pathway of its action was via mobilization of intracellular calcium and increased production of inositol phosphates (Kung et al. 1995). As Tg is the pro-thyroid hormone, inhibition of its production would result in hypothyroidism in AITD. The aim of the present study was to identify the specific site of action of IFN $\gamma$ on the $\mathrm{Tg}$ gene. Understanding the role and action of IFN $\gamma$ on the $\mathrm{Tg}$ gene may enable us to identify specific targets for intervention in AITD.

\section{MATERIALS AND METHODS}

\section{Cells}

Normal para-adenomatous human thyroid tissues obtained from subjects undergoing hemithyroidectomy were enzymatically digested and cultured in R.p.m.I-1640 medium supplemented with $10 \%$ fetal calf serum (Hinds et al. 1981). These cells had been confirmed previously to respond to TSH stimulation by the production of CAMP and release of tri-iodothyronine and $\mathrm{Tg}$. For the stimulation experiment, the cells were resuspended in $1 \%$ bovine serum albumin at a concentration of $10^{6} / \mathrm{ml}$. Recombinant human IFN $\gamma(\operatorname{rhIFN} \gamma, 500 \mathrm{IU} / \mathrm{ml}$; Genzyme Diagnostics, Cambridge, MA, USA) was added to the culture for between 2 and $48 \mathrm{~h}$. Bovine TSH (bTSH), forskolin, genistein and other chemicals were obtained from Sigma Chemicals Co. (St Louis, MO, USA).

\section{Transient transfection study}

A 565 bp fragment (position -530 to +34 ) spanning the transcriptional start site of the human
TABLE 1. Results of transient transfection with $\mathrm{p} \mathrm{Tg}$. luc in human thyrocytes

p Tg. luc

p Tg. luc +bTSH $(10 \mathrm{mU} / \mathrm{l})$

p Tg. luc + IFN $\gamma(500 \mathrm{IU} / \mathrm{l})$

p Tg. luc +bTSH+IFN $\gamma$

p Tg. luc + forskolin $\left(10^{-5} \mathrm{M}\right)$

Positive pGL-control luciferase plasmid

No transfection

Relative light units

4359

17330

2695

2650

8108

13347

191

$\mathrm{Tg}$ gene was subcloned into the pGL2-enhancer luciferase plasmid (Promega, Madison, WI, USA) between the KpnI and XhoI cloning sites. The sequence contains the cAMP-responsive region which is located within the first $250 \mathrm{bp}$ of the promoter, as well as the TATA box (Christophe et al. 1985, 1989). For the transient transfection experiment, $2.5 \mu \mathrm{g}$ recombinant $\mathrm{p} \mathrm{Tg}$. luciferase (p Tg. luc) plasmid was introduced into the human thyroid cell culture by lipofectum-mediated transfection (Transfectam Assay, Promega). To monitor for transfection efficacy, the cells were co-transfected with $0.5 \mu \mathrm{g} \beta$-galactosidase plasmid. Transfected cells were cultured in the presence or absence of rhIFN $\gamma$ for $48 \mathrm{~h}$. Cell extracts were prepared and the luciferase and $\beta$-galactosidase activities were determined. In each experiment, the results were adjusted for the $\beta$-galactosidase activity.

To determine the minimal sequence in the $\mathrm{Tg}$ promoter responsible for the action of IFN $\gamma$, exonuclease III was used to generate a set of $5^{\prime}$ deletions from the $\mathrm{Tg}$ promoter fragment. The deleted DNA was subcloned into the luciferase plasmid for transient transfection experiments. For confirmation, all transfection studies were repeated three times.

\section{Cell extracts}

Nuclear extracts were prepared according to the method described by Dignam et al. (1983). Cells $\left(10^{9}\right)$ were harvested from the culture and collected by centrifugation. The cell pellet was suspended in $10 \mathrm{mM}$ Tris- $\mathrm{HCl}, \mathrm{pH} 7 \cdot 9,1.5 \mathrm{mM} \mathrm{MgCl}_{2}, 10 \mathrm{mM}$ $\mathrm{KCl}, 0.5 \mathrm{mM}$ dithiothreitol at $4{ }^{\circ} \mathrm{C}$ for $10 \mathrm{~min}$ and again collected by centrifugation and broken down by Dounce homogenization in a small volume of the same buffer. The cell lysate was centrifuged at $25000 \boldsymbol{g}$ for $20 \mathrm{~min}$ to remove residual cytoplasmic material. The crude nuclei were further broken down by Dounce homogenization in the presence of $25 \%$ glycerol. Particulate matter was removed by 
TABLE 2. Transient transfection with deletion mutants of Tg promoter

\begin{tabular}{|c|c|c|c|}
\hline \multirow[b]{3}{*}{ Construct } & & \multicolumn{2}{|c|}{ Relative light units } \\
\hline & & Without IFN $\gamma$ & With IFN $\gamma$ \\
\hline & & & \\
\hline & -1 & 8662 & 4181 \\
\hline-530 & +34 & & \\
\hline$\longmapsto$ & 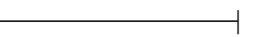 & 7308 & 3642 \\
\hline-470 & +34 & & \\
\hline$\longmapsto$ & -1 & 7324 & 4591 \\
\hline-388 & +34 & & \\
\hline$\longmapsto$ & $-\mid$ & 7943 & 7690 \\
\hline-258 & +34 & & \\
\hline$\longmapsto$ & -1 & 919 & 917 \\
\hline-530 & -171 & & \\
\hline
\end{tabular}

centrifugation. The extract was collected for protein content estimation and stored at $-80{ }^{\circ} \mathrm{C}$.

\section{Gel retardation assays}

DNA fragments of $\mathrm{Tg}$ promoter were incubated with nuclear extracts $(10 \mu \mathrm{g})$ at $37^{\circ} \mathrm{C}$ for $10 \mathrm{~min}$ (Gel Shift Assay Systems, Promega). After $30 \mathrm{~min}$ incubation with $\gamma-{ }^{32} \mathrm{P}$-labeled DNA fragment (5000-10 000 c.p.m.), free and bound DNA were separated by electrophoresis on $6 \%$ polyacrylamide gels. For competition experiments, the $\mathrm{AP}_{2}$ consensus oligonucleotide $(1.75 \mathrm{pmol})$ was added as the non-specific competitor.

\section{DNA footprinting assay}

The $\mathrm{Tg}$ promoter fragment was labeled with $\mathrm{T} 4$ polynucleotide kinase and $20 \mu \mathrm{g}$ nuclear protein extract was incubated with the labeled $\mathrm{Tg}$ promoter fragment at $37^{\circ} \mathrm{C}$ for $3 \mathrm{~h}$. The top strand probe was prepared by removing the label from the $3^{\prime}$ end of the fragment by digestion with XhoI. DNA footprinting was carried out with the Core Footprinting System (Promega). Sequencing was performed using T7 DNA polymerase (Sequenase Version 2.0 DNA Sequencing Kit, United States Biochemical, Amersham, IL, USA) and the DNA was loaded onto a $6 \%$ polyacrylamide sequencing gel.

\section{RESULTS}

\section{Transfection study}

In transient transfection experiments bTSH $(10 \mathrm{mIU} / \mathrm{l})$ increased luciferase activity by $2-$ to 4-fold and IFN $\gamma$ decreased luciferase activity by $60 \%$. These responses to bTSH and IFN $\gamma$ were similar to those observed with the endogenous $\mathrm{Tg}$ gene (Kung \& Lau 1990), suggesting that the minimal promoter element contained the DNA signals necessary for $\mathrm{TSH}$ and $\mathrm{IFN} \gamma$ regulation. Forskolin $\left(10^{-5} \mathrm{M}\right)$ increased luciferase activity twofold. Table 1 shows the typical result from one set of experiments.

Systematic deletion experiments were performed to determine the minimal DNA sequence necessary for the action of IFN $\gamma$. The suppressive effect of IFN $\gamma$ was lost when cells were transfected with mutant -258 to +34 , suggesting that the minimal region required for the IFN $\gamma$ response lay between position -388 and -258 (Table 2). Transfection with mutant -530 to -171 did not show any luciferase activity, as the regulatory elements of the $\mathrm{Tg}$ promoter lay within the first $250 \mathrm{bp}$ of the $5^{\prime}$ flanking region.

\section{Gel shift assay}

Gel shift assays demonstrated a mobility shift with $\mathrm{Tg}$ promoter sequence -316 to -199 (Fig. 1). Specific competition and mobility shift resulting in a retarded band was observed with nuclear extracts prepared from thyrocytes that had been incubated with IFN $\gamma$ for $4 \mathrm{~h}$ (lane d). Nuclear extracts prepared from control thyrocytes did not demonstrate mobility shifting (lane b). Incubation with $\mathrm{IFN} \gamma$ for $2 \mathrm{~h}$ revealed a retarded band of weaker intensity (lane c), whereas incubation for $8 \mathrm{~h}$ (lane e) or longer (data not shown) did not demonstrate any mobility shift. In the presence of the non-specific competitor $\mathrm{AP}_{2}$ consensus oligonucleotide, the specific retarded band persisted (lane f).

\section{DNA footprinting experiment}

This showed that the action of IFN $\gamma$ was mediated via a trans-acting protein which complexed to the 


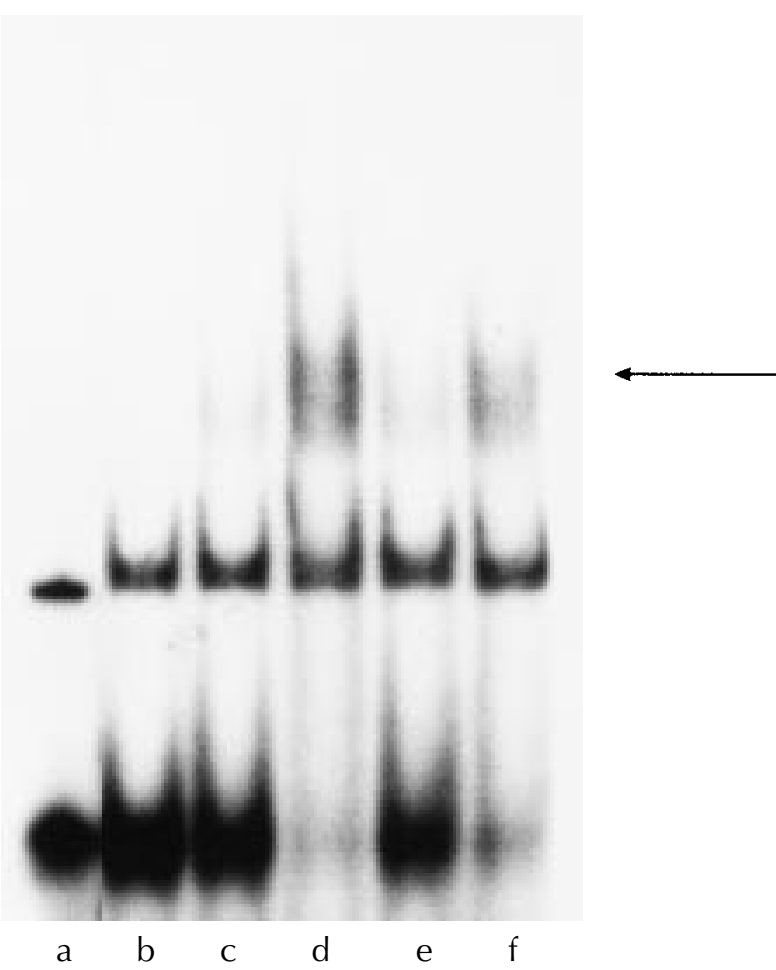

FIGURE 1. Gel shift assays were carried out with ${ }^{32} \mathrm{P}$-labeled probe $(-316$ to -199 of $\mathrm{Tg}$ promoter $)$. Lane a, probe only; lanes b-e, nuclear extracts from IFN $\gamma$-treated cells, and 5 pmol specific competitor $(-316 /-199)$. Nuclear proteins from control thyrocytes (lane b), or incubation with IFN $\gamma$ for $2 \mathrm{~h}$ (lane c), $4 \mathrm{~h}$ (lane d), $8 \mathrm{~h}$ (lane e). Lane f, non-specific competitor $\mathrm{AP}_{2}$ oligonucleotide and nuclear extracts from thyrocytes incubated with IFN $\gamma$ for $4 \mathrm{~h}$. Arrow shows position of the retarded band.

DNA sequence -282 to -262 TTGAGCCTGT TCCCTCCAAA. Position -272 to -261 TTCC CTCCAA is homologous to the gamma-interferon activation site (GAS) consensus sequence TTNC ${ }_{\mathrm{T}}$ NNNAA (Decker et al. 1991). Binding was visualized from nuclear extracts obtained from cells that were incubated with IFN $\gamma$ for $2-4 \mathrm{~h}$ (Fig. 2). Nuclear extracts from cells incubated with IFN $\gamma$ for a longer period did not demonstrate binding to the DNA, suggesting that the nuclear protein was turned on for only $4 \mathrm{~h}$ or less. Treatment with genistein, a specific tyrosine protein kinase inhibitor, resulted in loss of action of IFN $\gamma$ (Fig. 3).

\section{DISCUSSION}

The results of this study demonstrated that the $\mathrm{Tg}$ gene contained the specific GAS in its promoter

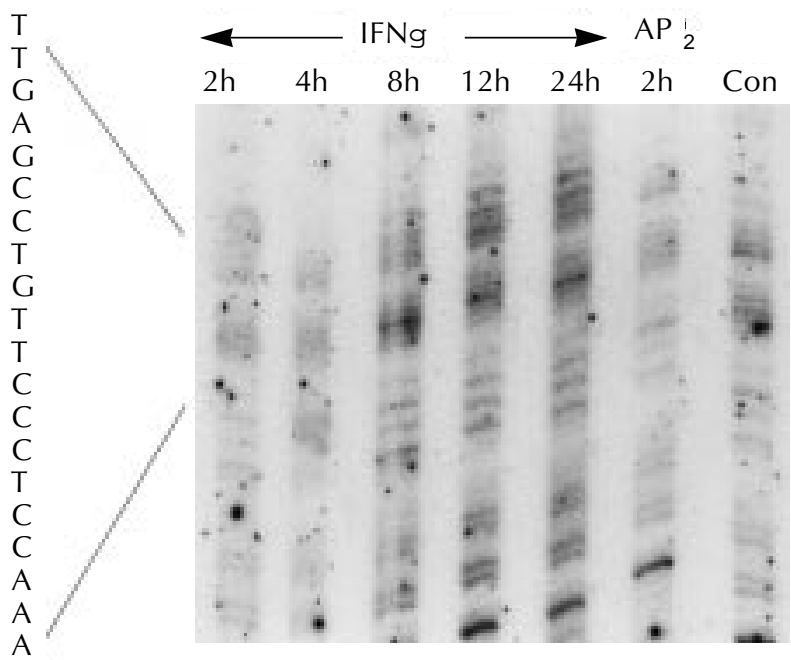

FIGURE 2. DNA footprinting revealed protein complexing to DNA position -282 to -262 of the $\mathrm{Tg}$ promotor. Binding was observed from nuclear extracts of cells incubated with IFN $\gamma$ for $4 \mathrm{~h}$ or less. $\mathrm{AP}_{2}$ protein showed no complexing to the $\mathrm{Tg}$ promoter.

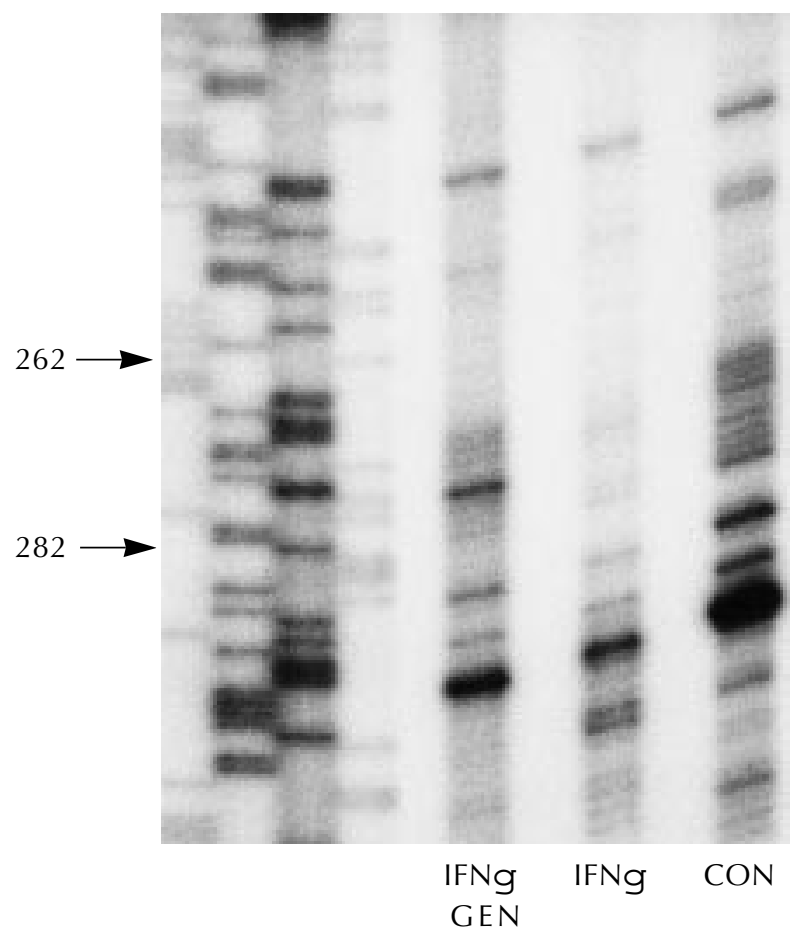

FIGURE 3. DNA footprinting: co-treatment with genistein $(50 \mu \mathrm{g} / \mathrm{ml})$ resulted in loss of action of IFN $\gamma$, and no binding of the nuclear extracts to the $\mathrm{Tg}$ promotor was observed. GEN, genistein; CON, control.

region and that the action of $\mathrm{IFN} \gamma$ was mediated through a trans-acting protein. Among the few thyroid-specific proteins, the $\mathrm{Tg}$ gene is the best 
characterized (Musti et al. 1986). The molecular mechanisms involved in the tissue-specific and hormone-dependent expression of the $\mathrm{Tg}$ gene have been studied both in primary cells and in transgenic animals (Civitareale et al. 1989, Ledent et al. 1990). Using nuclear run-on experiments and measurement of steady state mRNA levels, we had previously demonstrated that IFN $\gamma$ exerted an inhibitory action on $\mathrm{Tg}$ gene transcription (Kung \& Lau 1990). However, Nishikawa et al. (1993) suggested that this effect of IFN $\gamma$ on the Tg gene was probably secondary to the negative effect of IFN $\gamma$ on TSH receptor expression. The results obtained from the present study confirmed that $\mathrm{IFN} \gamma$ had a direct specific effect on the $\mathrm{Tg}$ gene which could be inhibited by genistein, a specific tyrosine protein kinase inhibitor. We further showed that the action of IFN $\gamma$ on the human $\mathrm{Tg}$ gene was mediated by a trans-acting protein, similar to the action of IFN $\gamma$ on the lymphoid cells. Whether this trans-acting protein is the same gamma-interferon activation factor (GAF) as described for the lymphoid cells remains to be confirmed (Decker et al. 1991). In the lymphoid cell lines, partial purification of GAF revealed a prominent $91 \mathrm{kDa}$ protein, and this GAF activity was inhibited by antibodies to STAT $1 \alpha$ (Khan et al. 1993). The STAT (signal transducers and activators of transcription) proteins are activated through phosphorylation of tyrosine residues of the Jak-1 and -2 kinases (Igarashi et al. 1993, Muller et al. 1993). These proteins are then translocated to the nucleus where, by themselves or in combination with other DNA binding proteins, they bind to the GAS and stimulate transcription (Darnell et al. 1994). We had previously also demonstrated that the effect of IFN $\gamma$ on the mobilization of intracellular calcium and the production of inositol phosphates in human thyrocytes were inhibited by genistein (Kung et al. 1995), suggesting that the signal transduction mechanism for IFN $\gamma$ was the same for both lymphoid and non-lymphoid cells. However, whereas IFN $\gamma$ produced a stimulatory action on the responsive genes in the lymphoid cells, IFN $\gamma$ exerted an inhibitory effect on the $\mathrm{Tg}$ gene. Whether this difference lies in the transcriptional factor that differs between lymphoid cells and the thyroid epithelial cells or whether the $\mathrm{Tg}$ gene also binds other proteins which modulate the promoter activity remains to be elucidated. Although the induction of the transcriptional protein in the thyrocytes lasted for only $4 \mathrm{~h}$, the effect of the IFN $\gamma$-induced inhibition of $\mathrm{Tg}$ transcription continued for much longer and lasted for $48 \mathrm{~h}$ as reported previously (Kung \& Lau 1990). The same phenomenon was observed in the responsive genes in the lymphoid cells.

Apart from its action on the $\mathrm{Tg}$ gene, IFN $\gamma$ had also been reported to inhibit the transcription of TPO and TSH receptor gene (Nagayama et al. 1987, Ashizama et al. 1989) by a reduction of steady-state mRNA level. The signaling mechanism of IFN $\gamma$ for these two genes has not been described and it is not certain whether these genes also contain the GAS in their promotor region. Searching the $5^{\prime}$ flanking sequence of the human TPO gene revealed two regions in the distal $5^{\prime}$ area, -2475 to -2466 and -1994 to -1985 , showing some degree of homology to the minimal sequence of the GAS (Kimura et al. 1989). Whether these two regions are important in the control of TPO gene transcription and whether they are the sites of IFN $\gamma$ action remain to be confirmed. No GAS region could be identified from the published sequence of the TSH receptor 5' flanking region.

At present, the pathogenesis and the initiation of AITD is far from well understood. Although early data suggested that aberrant expression of class II antigen by thyroid epithelial cells may be the initiating process of AITD (Bottazzo et al. 1983), recent studies found that expression of class II antigen alone, without the presence of a co-stimulatory second signal, actually conferred peripheral tolerance and led to T cell anergy (Miller \& Morahan 1992, Weetman 1995). Whether IFN $\gamma$ has a role in the initiation of AITD is uncertain. Nevertheless, the presence of the GAS in the promoter sequence of the $\mathrm{Tg}$ gene confirms a specific action of IFN $\gamma$ in thyroid hormone metabolism. The clarification of the cellular action of IFN $\gamma$ on the $\mathrm{Tg}$ gene enables us to have a better understanding of how these cytokines affect the cellular function of and the hormone production by the thyrocytes. The identification of the activation signals and biological function of these cytokines on the thyroid-specific antigens may enable us to develop alternative immuno-modulatory agents for AITD.

\section{ACKNOWLEDGEMENTS}

The authors wish to thank Prof. Stephen Chung for advice, Miss Michelle Kung for technical support and Miss Carlina $\mathrm{Ng}$ for typing the manuscript. This project was supported by the Research Grant Committee, Hong Kong (account no. 338/041/0003, The University of Hong Kong).

The results of part of this work were presented to the Xth International Congress of Endocrinology, San Francisco, USA, June 1996. 


\section{REFERENCES}

Ashizama K, Yamashita S, Nagayama Y, Kimura H, Hirayu H, Izume M \& Nagataki S 1989 Interferon- $\gamma$ inhibits thyrotropin-induced thyroidal peroxidase gene expression in cultured human thyrocytes. Fournal of Clinical Endocrinology and Metabolism 69 475-477.

Bottazzo GF, Pujol-Borrell R, Hanafusa T \& Feldmann M 1983 Role of aberrant HLA-DR expression and antigen presentation in induction of endocrine autoimmunity. Lancet 2 1115-1119.

Christophe D, Cabrer B, Bacolla A, Targovnik H, Pohl V \& Vassert G 1985 An unusually long poly(purine)poly(pyrimidine) sequence is located upstream from the human thyroglobulin gene. Nucleic Acids Research 13 5127-5144.

Christophe D, Gerard C, Juvenal G, Bacolla A, Teugels E, Ledent C, Christophe-Hobertus C, Dumont JE \& Vassart G 1989 Identification of a cAMP-responsive region in thyroglobulin gene promoter. Molecular and Cellular Endocrinolgy 64 5-18.

Civitareale D, Lonigro R, Sinclair A \& Di Lauro R 1989 A thyroid-specific nuclear protein essential for tissue-specific expression of the thyroglobulin promoter. EMBO Fournal 8 2537-2542.

Darnell Jr JE, Kerr IM \& Stark GR 1994 Jak-STAT pathways and transcriptional activation in response to IFNs and other extracellular signalling proteins. Nature $2641415-1421$.

Decker T, Lew DJ, Mirkovitch J \& Darnell JE 1991 Cytoplasmic activation of GAF, an IFN- $\gamma$-regulated DNA-binding factor. EMBO Fournal 10 927-932.

Del-Prete GF, Tiri A, Mariotti S, Pinchera A, Ricci M \& Romagnani S 1987 Enhanced production of gammainterferon by thyroid-derived $\mathrm{T}$ cell clones from patients with Hashimoto's thyroiditis. Clinical and Experimental Immunology 69 323-331.

Dignam JD, Lebovitz RM \& Roeder RG 1983 Accurate transcription initiation by RNA polymerase II in a soluble extract from isolated mammalian nuclei. Nucleic Acids Research 11 1475-1489.

Hamilton F, Black M, Farquharson MA, Stewart C \& Foulis AK 1991 Spatial correlation between thyroid epithelial cells expressing class II MHC molecules and interferon-gammacontaining lymphocytes in human thyroid autoimmune disease. Clinical and Experimental Immunology 83 64-68.

Hinds WE, Takai N, Rapoport B, Filetti S \& Clark OH 1981 Thyroid stimulatory immunoglobulin bioassay using cultured human thyroid cells. Fournal of Clinical Endocrinology and Metabolism 52 1204-1210.

Igarashi K, David M, Finbloom DS \& Larner AC 1993 In vitro activation of the transcription factor gamma interferon activation factor by gamma interferon: evidence for a tyrosine phosphatase/kinase signalling cascade. Molecular and Cellular Biology 13 1634-1640.

Khan KD, Shuai K, Lindwall G, Maher SE, Darnell JE \& Bothwell ALM 1993 Induction of the Ly-6A/E gene by interferon $\alpha / \beta$ and $\gamma$ requires a DNA element to which a tyrosine-phosphorylated $91-\mathrm{kDa}$ protein binds. Proceedings of the National Academy of Sciences of the USA 90 6806-6810.

Kimura S, Hong YS, Kotani T, Ohtaki S \& Kikkawa F 1989 Structure of the human thyroid peroxidase gene: comparison and relationship to the human myeloperoxidase gene. Biochemistry 28 4481-4489.

Kung AWC \& Lau KS 1990 Interferon $\gamma$ inhibits thyrotropininduced thyroglobulin gene transcription in cultured human thyrocytes. Fournal of Clinical Endocrinology and Metabolism 70 1512-1517.

Kung AWC, Ma L \& Lau CS 1992 The role of interferongamma in lymphocytic thyroiditis: its functional and pathological effect on human thyrocytes in culture. Clinical and Experimental Immunology 87 261-265.

Kung AWC, Lau KS \& Wong NS 1995 Interferon- $\gamma$ increases intracellular calcium and inositol phosphates in primary human thyroid cell culture. Endocrinology 136 5028-5033.

Ledent C, Parmentier M \& Vassart G 1990 Tissue-specific expression and methylation of a thyroglobulin chloramphenicol acetyltransferase fusion gene in transgenic mice. Proceedings of the National Academy of Sciences of the USA 87 6176-6180.

Miller JFAP \& Morahan G 1992 Peripheral T cell tolerance. Annual Review of Immunology 10 51-69.

Muller M, Briscoe J, Laxton C, Guschin D, Ziemiecki A, Silvennoinen O, Harpur AG, Barbieri G, Witthuhn BA, Schindler C, Pellegrini S, Wilks AF, Ihle JN, Stark GR \& Kerr LM 1993 The protein tyrosine kinase JAK1 complements defects in interferon-alpha/beta and -gamma signal tranduction. Nature 366 129-135.

Musti AM, Avvedimento EV, Polistina C, Ursini VM, Obici S, Nitsch L, Cocozza S \& Di Lauro R 1986 The complete structure of the rat thyroglobulin gene. Proceedings of the National Academy of Sciences of the USA 83 323-327.

Nagayama Y, Izumi M, Ashizawa K, Kiriyama T, Kokoyama N, Morita S, Ohtakara S, Fukuda T, Eguchi K \& Morimoto I 1987 The inhibitory effect of interferon-gamma on the response of human thyrocytes to TSH stimulation. Fournal of Clinical Endocrinology and Metabolism 64 949-959.

Nishikawa T, Yamashita S, Namba H, Usa T, Tominaga T, Kimura H, Izumi M \& Nagataki S 1993 Interferon- $\gamma$ inhibition of human thyrotropin receptor gene expression. Fournal of Clinical Endocrinology and Metabolism 77 1084-1089.

Volpe R 1993 Suppressor T lymphocyte dysfunction is important in the pathogenesis of autoimmune thyroid disease: a perspective. Thyroid 3 345-352.

Watson PF, Pickerill AP, Davies R \& Weetman AP 1994 Analysis of cytokine gene expression in Graves' disease and multinodular goitre. Fournal of Clinical Endocrinology and Metabolism 79 355-360

Weetman AP 1995 Antigen presentation in endocrine autoimmunity. Fournal of Autoimmunity 8 305-312.

Weetman AP \& McGregor AM 1994 Autoimmune thyroid disease: further developments in our understanding. Endocrine Reviezus 15 788-830.

REVISED MANUSCRIPT RECEIVED 23 October 1997 